\title{
Government Management in Village-Owned Enterprises in Increasing Village Original Income In Kampar District
}

\author{
Zainal $^{1}$, Fidya Nurdasanah Putri ${ }^{1}$ \\ zainal.ip@soc.uir.ac.id \\ ${ }^{1}$ Universitas Islam Riau, Indonesia
}

\begin{abstract}
The high arrears of Savings and Loans at the Village-Owned Enterprises of Kampung Patin, Kampar Regency, is the lack of public awareness to pay off their debts. The purpose of this study was to examine government management in the savings and loan business in Kampung Patin Village, Kampar Regency. This research was conducted using qualitative research methods. The results showed that the government management of Village Owned Enterprises in increasing Village Original Income in Koto Mesjid Village, XIII Koto Kampar District, Kampar Regency had not gone well, this was caused by several factors, such as freezing of Savings and Loans and switching to fish feed loans. . In the form of providing assistance by BUMDes Kampung Patin is still not right because there are still many people who need the Savings and Loans business unit to be reactivated for business capital assistance.
\end{abstract}

Keywords: Management, Government and Village-Owned

\section{Introduction}

Village-Owned Enterprises (BUMDes) are a village business forum, with the spirit of independence, togetherness and mutual cooperation between the Village Government and the community, which develop local assets to provide services to community members and increase the economic income of the community and the village. BUMDes of course also intends to contribute to poverty alleviation and the achievement of people's welfare (Sutoro, 2014; 248) in (Seimbiring, 2017).

One of the efforts made by the village government, especially in improving the welfare and economy of underprivileged communities, is by establishing Village Owned Enterprises (BUMDes). BUMDes is technically an institution that encourages an increase in Village Original Income (PADes). Village-Owned Enterprises (BUMDes) are also village business institutions managed by the community and village government, as an institution formed to strengthen the village economy and formed based on the needs and potential of the village. But in its implementation there are several problems that arise.

BUMDes is an institution formed by the village government and the community manages the institution based on the needs and the village economy. BUMDes is formed based on the applicable laws and regulations based on an agreement between village communities. The purpose of BUMDes is to improve and strengthen the village economy. BUMDes has a function as a commercial institution through offering local resources that aim to seek profit and social institutions through contributing to the provision of social services that favor the interests of the community. BUMDes has made a positive contribution to strengthening the rural economy in developing the community's economy (Alkadafi, 2014) in (Gufran and Hajirin, 
2019).

Village-Owned Enterprises (BUMDes) are defined by Law Number 6 of 2014 as a business entity whose capital is wholly or most of the capital owned by the village through direct participation from village assets which are separated to manage assets, services and other businesses for the benefit of the welfare of the village community. In simple terms, BUMDes is a village-owned enterprise in charge of managing wealth related to village assets. However, it is possible that BUMDes can ask for loans from other parties if they experience business capital difficulties, this is expressed by (Kurnia 2015) in (Gufran and Hajirin, 2019).

Taking into account several things, Koto Mesjid Village on March 16, 2015 established a Village-Owned Enterprise or often called BUMDes and was named "Kampung Patin". With the establishment of BUMDes Kampung Patin is expected to be able to utilize the potential and assets of the village to build the welfare of the residents of Koto Mesjid Village, because it is no longer a "top-down" program or program package from the regional or central government, but rather village development that is driven by the power of the residents. BUMDes Kampung Patin was established by taking into account the potential of the village, Koto Mesjid Village consists of 4 hamlets and the majority of the population is farmers and most of them are also freshwater fish farming.

From the explanation above and supported by research data, the phenomena researchers observed include: 1) The high level of debt arrears in BUMDes Kampung Patin. Here it can be seen from the economy of the people whose livelihoods in the village are as rubber farmers and freshwater fish farming, if the price of rubber drops then the farmer cannot pay the debt, because the results from the rubber collected in one week are only enough to eat. And if those who cultivate freshwater fish harvest and do not reach the target, the impact is also not paying their debts to BUMDes; 2) Lack of awareness from the community to repay loans that have been given by BUMDes, seen from the debts that have not been paid by the community for years; 3) The lack of firmness from the BUMDes regarding the community who does not pay the loan credits that have been given, can be seen from the BUMDes not withdrawing the guarantee, because there is still compassion or there are interrelationships such as family relationships with the BUMdes; 4) The lack of supervision from the BUMDes Commissioner on the course of the credit withdrawal process, seen from the customer data that the author found in 2019, namely those who did not pay as many as 57 creditors of Rp. 258,319,430,- and 5) The lack of BUMDes in increasing PADes, can be seen from the data on the addition of PADes annually.

Based on the phenomena that the authors found in the field as described above, the authors are interested in researching it further by raising the title of the research "Government Management in Village-Owned Enterprises in Increasing Village Original Income in Koto Mesjid Village, XIII Koto Kampar District, Kampar Regency".

Rulers in the terminology of state science, political science, administrative science are usually with the term government. Meanwhile, government activities in exercising state power are referred to as government. (Salam, 2007; 34) in (Suharyadi and Mohamad Aji Insani, 2016).

Then it is not much different from the meaning of the definition of government above, Salam defines government as follows: "Basically, the government is a group of people who are given legal power by the local community to carry out regulations on interactions that occur in community interactions to meet the needs and necessities of daily life. days, so that these interactions can run in harmony." (Salam, 2007;34) in (Suharyadi and Mohamad Aji Insani, 2016).

The definition of government is: "An organ that is authorized to process public services and is obliged to process civil services for everyone through government relations when 
needed, in accordance with the demands (expectations) that are ordered. In that connection, even foreign nationals or anyone who is legally (legally) in the territory of Indonesia at any time has the right to receive certain civil services and the government is obliged to provide them." (Ndraha, 2015;6).

The management function is the basic elements that will always exist and are inherent in the management process that will be used as a reference by managers in carrying out activities to achieve goals. Management functions:

1. Planning Function

Planning is determining the work that must be carried out by the group to achieve the goals outlined, planning includes decision-making activities, because it includes the selection of decision alternatives.

In a fishery business unit, the thing that must be planned in advance is to determine the number of fish ponds that will be used as a place for fish cultivation.

2. Organizing Function

Organizing includes: (a) dividing the components of activities needed to achieve the objectives into groups, (b) assign tasks to a manager to carry out the grouping and (c) assign authority among groups or organizational units.

In this organization, the thing that must be done by cultivators is to do the work of giving lime to the pond that will be used for freshwater fish cultivation, the purpose of giving this lime is to kill pests in the pond, so as not to eat the fish seeds that will be put into the pond. 3. Actuating Function

Actuating includes activities carried out by a manager to initiate and continue the activities determined by the planning and organizing elements so that goals can be achieved. In this driving function, the thing that might be done is feeding the fish that are being cultivated, the feed is feed made by BUMDes employees.

4. Controlling Function

Controlling includes the continuation of tasks to see if activities are carried out according to plan. The implementation of activities is evaluated and unwanted deviations are corrected so that the goals can be achieved properly (Terry, 2013; 17-18) in (Suharyadi and Insani, 2016).

\section{Method}

The type of research used by the author in this study is using qualitative methods. Qualitative research is a method for exploring and understanding the meaning that a number of individuals or groups of people ascribe to social or humanitarian problems. This qualitative research involves significant efforts (Creswell, 2016; 4-5).

The purpose of qualitative research generally includes information about the main phenomena explored in the study, research participants, and research locations. The purpose of qualitative research can also state the chosen research design. This objective is written in "technical" terms. This research is derived from the language of qualitative research.

This study aims to describe the actual or actual situation regarding Government Management in Village Owned Enterprises (BUMDes) in Increasing Village Original Income in Koto Mesjid Village, XIII Koto Kampar District, Kampar Regency.

\section{Result And Discussion}


This study aims to describe the actual or actual situation regarding Government Management in Village Owned Enterprises (BUMDes) in Increasing Village Original Income in Koto Mesjid Village, XIII Koto Kampar District, Kampar Regency.

\section{Planning Function}

Based on the results of interviews with key informants, namely Mr. Mustakim, S.Pd, researchers can conclude that Government Management in Village-Owned Enterprises in Increasing Village Original Income in Koto Mesjid Village, XIII Koto Kampar District, Kampar Regency in planning indicators is quite instrumental, This is evidenced by the sub-indicators, namely determining the work to be carried out by the group, and decision-making activities.

Furthermore, the researcher continued the interview with the Head of Fishery Business Unit of BUMDes Kampung Patin, namely Mr. Khairul Rahmad on Thursday 7 January 2021 at 13.30 WIB regarding the planned activities to be carried out by BUMDes Kampung Patin in the Fisheries Business Unit, Mr. Khairul Rahmad gave his opinion:

"I, as the Head of the Fisheries Business Unit, will certainly give the best for the BUMDes of Kampung Patin, my plan as the Head of the Fisheries Business Unit of the BUMDes of Kampung Patin I will further develop the sale of smoked catfish and fresh catfish by looking for wholesalers or toke salai and selling them to local people," he said. them, because the smoked catfish is very well known in our village. Of course, if the sale of smoked catfish is high in the market and automatically the profits obtained by the Fisheries Business Unit are also high. And now the BUMDes Village Patin Business Unit also provides pool rentals for cultivating catfish."

Based on the results of interviews conducted with the informant, namely Mr. Khairul Rahmad, the researcher can conclude that Government Management in Village Owned Enterprises in Increasing Village Original Income in Koto Mesjid Village in the Planning indicator (Plainning) is quite instrumental, this is evidenced by the sub-indicators, namely determining jobs that must be carried out by groups and decision-making activities. From the interview with Mr. Khairul Rahmad, we can see that the BUMDes Fisheries Business Unit wants to develop the marketing of smoked catfish and fresh catfish and rent a pond for entrepreneurs or people who need a pond to cultivate catfish, of course this will also have a very positive effect on increasing Village Original Income.

Furthermore, the researcher conducted an interview with the Treasurer of the BUMDes Kampung Patin, Ms. Rosmaniar, on Thursday, January 7, 2021 at 14.30 WIB regarding how to prepare the financial plan for the BUMDes Kampung Patin, Ms. Rosmaniar gave her opinion:

"The way I arrange it is by making money coming in and money going out every month, the money coming in is in the form of a business unit deposit, for example, such as the profits earned by the business unit, and the money going out is as needed by the BUMDes management such as a printer. And I also make every money out of a receipt if what you buy is in the form of goods."

Based on the results of interviews with informants, namely Ms. Rosmaniar, researchers can conclude that Government Management in Village-Owned Enterprises in Increasing Village Original Income in Koto Mesjid Village in the Planning indicator (planning) is quite instrumental, this is proven by the sub-indicators, namely determining the work that must be carried out and decision-making activities. From the interview with Ms. Rosmaniar, we know that the activities carried out by Ms. Rosmaniar are based on sub-indicators of determining the work that must be carried out, namely recording incoming and outgoing money every month, and to ensure that there is no mistake later if there are items purchased, they are made receipt.

Next, the researcher conducted interviews with the community informant of Koto Mesjid Village, Mrs. Nursam, on Monday, January 25, 2021 at 10.00 WIB, about how the 
community responded to the establishment of BUMDes Kampung Patin and the planning of activities to be carried out in the future:

"My response to the establishment of BUMDes is that it can help the economy of the community in Koto Mesjid Village, and regarding the planned activities that will or have even been carried out by BUMDes, it is very helpful for people who really need it in the fisheries sector".

Based on the results of interviews with informants, namely Ms. Nursam, researchers can conclude that Government Management in Village-Owned Enterprises in Increasing Village Original Income in Koto Mesjid Village in the Planning indicator (planning) is quite instrumental, this is proven by the sub-indicators, namely determining the work that must be carried out and decision-making activities.

By carrying out business unit activities by BUMDes, the BUMDes management has also determined their respective jobs. From the explanation above, it can be concluded that Government Management in Village-Owned Enterprises in Increasing Village Original Income in Koto Mesjid Village in the Supervision indicator plays a significant role, this is proven from interviews of researchers with key informants and informants on the sub-indicators, namely determining the work to be carried out and activities decision-making.

From observations made in the field, researchers found that Village-Owned Enterprises in Koto Mesjid Village before dividing their business units, the administrators planned in advance what business units were established in accordance with the potential possessed by Koto Mesjid Village. And also don't forget to look at the direction of the community's economy which is more dominant, such as fisheries. And also BUMDes establish service business units, as needed by the local community but not in the village, such as BRILink (cash withdrawals, and transfers).

\section{Actuating Function}

What is meant by driving is to move the organization so that it runs in accordance with the respective division of labor and to mobilize all existing resources within the organization so that the work or activities carried out can go according to plan and achieve goals.

Based on the results of interviews conducted by researchers with key informants, namely Mr. Mustakim, S.Pd as Director of the Village-Owned Enterprises of Kampung Patin on Thursday 7 January 2021 at 10.00 WIB regarding when the BUMDes targets for activities or business units have been carried out with the aim of establishing BUMDes, one of which increases Village Original Income, Mr. Mustakim, S.Pd replied: "Every year, it is evaluated. Achieving or not achieving it can be seen at the Annual Accountability Village Meeting".

The next question regarding the source of the BUMDes funds in Kampung Patin, Mr. Mustakim, S.Pd gave the answer: "The sources of BUMDes funds start from village funds, as well as provincial financial assistance or called BKK".

The next question regarding how the Director of BUMDes Kampung Patin gives advice to members to work optimally or work harder, Mr. Mustakim, S.Pd gave the answer: "The way is to motivate, give rewards, and give appreciation when they succeed".

The next question regarding how BUMDes Kampung Patin with several business units can increase Village Original Income in Koto Mesjid Village, Mr. Mustakim S.Pd gave the answer:

"The way for BUMDes Kampung Patin to increase or provide original income to the village is the first, providing and providing feed assistance to people who need fish feed, if the fish are of sufficient size in the pan, it is BUMDes that takes care of harvesting and postharvesting. Second, BUMDes Kampung Patin also regulates market management activities and 
controls and manages market finances, for example asking for rent from traders in the market and using rent to repair the market if there is damage. Third, BUMDes Kampung Patin also provides services, namely BRILink, such as money transfers and cash withdrawals which can be charged Rp. 5,000 in one transaction. Fourth is by providing an odong-odong car which is Rp. 5,000. per person, as well as the ticket price for the natural tourism of Sugai Crow and Kompe Peak, which is Rp. 5,000. per person. The five BUMDes of Kampung Patin also provide fresh catfish, smoked catfish, and also cultivate catfish. Some of the things I have mentioned, BUMDes Kampung Patin quite a lot provides original income for the village".

Based on the results of interviews with key informants, namely Mr. Mustakim S.Pd, the researchers concluded that Government Management in Village-Owned Enterprises in Increasing Village Original Income in Koto Mesjid Village in the Mover indicator was quite proactive, this was proven from the sub-indicators, namely starting and continuing activities that have been determined and activities in accordance with the elements of planning and organizing so that the goals can be achieved. BUMDes carry out their activities based on planning elements carried out at the beginning of the formation of BUMDes and group activities, such as determining the head of business units and division of tasks.

Next, the researcher conducted an interview with the informant, namely Mr. Khairul Rahmad as Head of the BUMDes Fisheries Business Unit in Kampung Patin on Thursday 7 January 2021 at 13.30 WIB, regarding when the target for the fisheries business unit was achieved with the aim of establishing BUMDes, one of which was to increase Village Original Income. , Mr. Khairul Rahmad gave his opinion: "We see the achievement of a target for this business unit when we make a deposit every month whether there is an increase or decrease".

The next question regarding how the Head of the Fishery Business Unit of BUMDes Kampung Patin gives advice to members to work optimally or work harder, Mr. Khairul Rahmad gave his opinion: "I only give motivation to working members".

Based on the results of interviews with informants, namely Mr. Khairul Rahmad, the researchers concluded that Government Management in Village-Owned Enterprises in Increasing Village Original Income in Koto Mesjid Village in the Mover indicator plays a significant role, this is proven by the sub-indicators, namely starting and continuing the activities that have been carried out. set and activities in accordance with the elements of planning and organizing so that goals can be achieved. With BUMDes Kampung Patin continuing a business unit with very strong potential in the village, it will encourage an increase in Village Original Income.

Next, the researcher conducted an interview with an informant from the Koto Mesjid Village community, namely Ms. Nursam, on Monday, January 25, 2021 at 10.00 WIB, regarding what Ibuk's response was to whether or not the BUMDes coordinated.

\section{Controlling Function}

What is meant by supervision is a process to apply what work has been carried out, evaluate it and review it with the intention that the implementation of the work is in accordance with the initial plan. Supervision is a process of determining what must be achieved, namely standards, what must be done, namely implementation, assessing implementation and making improvements so that implementation is in accordance with the plan.

Based on the results of the interview with the informant, namely Mr. Dendi Riono SHi, the researcher can conclude that Government Management in Village Owned Enterprises in Increasing Village Original Income in Koto Mesjid Village in the supervision indicator is quite instrumental, this is proven by the sub-indicators, namely seeing the activities carried out according to plan and evaluate the activities carried out if there are deviations are corrected so 
that the objectives are achieved. With the activities carried out by BUMDes Kampung Patin, namely in the fisheries sector, independent feed houses, markets, services, and tourism, BUMDes succeeded in boosting Village Original Income and BUMDes also succeeded in achieving goals, one of which was to increase Village Original Income.

Next, the researcher conducted an interview with the informant, namely Mr. Khairul Rahmad as the Head of the BUMDes Village Patin Fisheries Business Unit on Thursday 7 January 2021 at 13.30 WIB, regarding what actions were taken to make improvements to the Patin Village BUMDes business unit that was having problems, Mr. Khairul Rahmad gave his opinion: "The action I took was to find a solution to the problem at hand, and negotiate with the directors, supervisors and commissioners".

The next question regarding how you, as the head of the unit, is to supervise the BUMDes business unit so that its goals can be achieved, namely increasing Village Original Income, Mr. Khairul Rahmad gives his opinion:

"My role as the head of the unit is to evaluate the activities carried out so that later if there are errors, they can be corrected again, so that later this goal can be achieved, namely increasing village original income".

Based on the results of interviews with informants, namely Mr. Khairul Rahmad, the researcher can conclude that Government Management in Village-Owned Enterprises in Increasing Village Original Income in Koto Mesjid Village in the supervision indicator is quite instrumental, this is proven by sub-indicators, namely seeing activities carried out according to plan and evaluating Activities carried out if there are deviations are corrected so that the objectives are achieved. With the activities carried out by BUMDes, Kampung Patin, especially in the Fisheries Sector, is one of the business units that has a big influence on increasing Village Original Income because most of the people have a livelihood in fisheries.

Furthermore, the researcher conducted an informant interview with the community of Koto Mesjid Village, namely Ms. Nursam on Monday, January 25, 2021 at 15.30 WIB, regarding how the community provided supervision over the activities of the BUMDes Kampung Patin and how Ibuk views activities that have problems, Ibuk Nursam gave her opinion:

"Based on what I see at this time, the community only reports if there is a problem to the BUMDes, but the BUMDes does not respond to reports from the community and my view on activities that have problems that do not involve the community, such as accountability meetings, there are people who are invited to participate in the event. the meeting, but not all people were given the invitation to the accountability meeting.

Based on the results of interviews with informants, namely Ms. Nursam, the researcher can conclude that Government Management in Village-Owned Enterprises in Increasing Village Original Income in Koto Mesjid Village in the Supervision indicator has less role, this is proven by sub-indicators, namely seeing activities carried out according to plan and evaluating activities implemented if there are deviations are corrected so that the objectives are achieved. The management of the BUMDes Kampung Patin is less involved in involving the community, as well as reports from the community, the BUMDes management is less responsive.

From the explanation above, it can be concluded that Government Management in Village-Owned Enterprises in Increasing Village Original Income in Koto Mesjid Village in the Supervision indicator plays a significant role, this is proven from interviews of researchers with key informants and informants on sub-indicators, namely seeing activities carried out according to plan and evaluate the activities carried out if there are deviations are corrected so that the objectives are achieved. 
From observations made in the field, researchers found that Village-Owned Enterprises in Koto Mesjid Village in carrying out their activities, especially in the fisheries sector, were supervised a lot starting from the Head of Business Units, Director of Fisheries, Supervisory Commissioners and of course the community. Supervision is very much needed by an organization, this supervision needs to be carried out by several people associated with an organization, with the establishment of BUMDes in the village, it cannot be separated from the supervision of the community, in order to achieve its goals, one of which is Increasing Village Original Income.

\section{Conclusion}

Based on the description above, this research can guarantee that the driving indicator is that there are still people who are in arrears in payments to the Savings and Loans business unit in BUMDes Kampung Patin. The management of BUMDes Kampung Patin is not firm in reprimanding people who are in arrears in payments, and there are also those who are still proposing why the Savings and Loans business unit is discontinued even though the community still needs business capital.

The Government Management at the Village-Owned Enterprises of Kampung Patin is under supervision, especially in carrying out its activities, especially in the fields ranging from the Head of the Business Unit, the Director of Fisheries, Supervision of the Commissioner and of course the community. Supervision is very much needed by an organization, this supervision needs to be carried out by several people associated with an organization, with the establishment of BUMDes in the village cannot be separated from community supervision, in order to achieve goals.

\section{References}

[1] Budiardjo, Miriram. 2009. Dasar-dasar Ilmu Politik. Jakarta: Gramedia

[2] Creswell, Jonh W. 2016. Research Design: Pendeklatan Metode Kualitatif, Kuantitatif, dan Campuran. Yogyakarta: Pustaka Pelajar.

[3] Ridwan. 2006. Hukum Administrasi Negara. Jakarta: PT Raja Grafindo Persada.

[4] Koentjaraningrat. 2009. Pengantar Antropologi Ilmu. Jakarta: PT Rineka Cipta.

[5] Labolo, Muhadam. 2014. Memahami Ilmu Pemerintahan. Jakarta: PT RajaGrafindo Persada.

[6] Ndraha, Taliziduhu. 2010. Budaya Organisasi. Jakarta: Rineka Cipta.

[7] Ndraha, Taliziduhu. 2015. Kybernologi (Ilmu Pemerintahan Baru). Jakarta: Rineka Cipta.

[8] Sugiyono. 2011. Metode Penelitian Kuantitatif Kualitatifdan R\&D. Bandung: Alfabeta.

[9] Syafiie, Inu Kencana. 2018. Pengantar Ilmu Pemerintahan. Bandung: PT Refika Aditama.

[10] Syafiie, Inu Kencana. 2011. Manajemen Pemerintahan. Bandung: Pustaka Reka Cipta.

[11] Sukasmanto. 2014. Rancang Bangun Bisnis Dan Pengelolaan BUM Desa. Yogyakarta: Forum Pengembangan Pembaharuan Desa.

[12] Sulastri, Lilis. 2014. Manajemen. Bandung: La Good's Publishing.

[13] Soekanto, Soerjono. 2013. Sosiologi Suatu Pengantar. Jakarta:Rajawali.

[14] Poerwadaminta. 2006. Kamus Besar Bahasa Indonesia. Jakarta: Balai Jakarta.

[15] Putra, Anom Surya. 2015. Badan Usaha Milik Desa: Spirit Usaha Kolektif Desa. Jakarta Pusat: Kementrian Desa, Pembangunan Daerah Tertinggal, Dan Transmigrasi Republik Indonesia

[16] Priyono. 2007. Buku Pengantar Manajemen. Sidoardjo. Universitas Bina Darma. 
[17] RPDN. 2007. Buku Panduan Pendirian Dan Pengelolaan Badan Usaha Milik Desa (BUMDes). Malang: Departemen Pendidikan Nasional Pusat Kajian Dinamika Sistem Pembangunan (PKDSP) Fakultas Ekonomi Universitas Brawijaya.

[18] Amelia Sri Kusuma Dewi. 2014. Peranan Badan Usaha Milik Desa (BUMDes)Sebagai Upaya Dalam Meningkatkan Pendapatan Asli Desa (PADes) Serta Menumbuhkan Perekonomian Desa. Fakultas Hukum, Universitas Brawijaya.

[19] Amelia Sri Kusuma Dewi. 2010. Alternatif Bentuk Badan Hukum yang Tepat dalam Pendirian Badan Usaha Milik Desa (BUMDes) sebagai Upaya Meningkatkan Pendapatan Asli Desa (PADes). Fakultas Hukum, Universitas Brawijaya.

[20] Dian Irawati dan Diana Elvianita Martanti. 2017. Transparansi Pengelolaan Laporan Keuangan BUMDes Terhadap Pelaporan Aset Desa (Studi Fenomenologi Pada BUMDes Desa Karangbendo Kec Ponggok Kab Blitar). Universitas Islam Balitar.

[21] Gufran dan Hajirin. 2019. Pelaksanaan BUMdes dalam meningkatkan pendapatan masyarakat dan pendapatan asli desa di kecamatan Belo Kabupaten Bima. Sekolah Tinggi Ilmu Hukum (STIH) Muhammadiyah Bima.

[22] Helmey Willy Amanda. 2015. Strategi Pemabgunan Desa Dalam Meningkatkan Pendapatan Asli Desa Melalui Badan Usaha Milik Desa (BUMDes) (Studi Pada Badan Pengelola Air Minum (BPAM) Di Desa Ketapanrame Kecamatan Trawas Kabupaten Mojokerto). S1 Ilmu Administrasi Negara, Fakultas Ilmu Sosial, Universitas Negeri Surabaya.

[23] Herry Suharyadi dan Mohamad Aji Insani. 2016. Manajemen Pemerintahan Dalam Program Unit Reaksi Cepat Tambal Jalan Di Kota Bandung Tahun 2015. Program Studi Ilmu Pemerintahan Fakultas Ilmu Sosial dan Ilmu Politik Universitas Padjadjaran.

[24] Jaryono dan Tohir. 2019. Analisis Kinerja BUMDes Mitra Usaha Makmur Dalam Pengaruhnya Terhadap Pendapatan Asli Desa (PADes) Desa Susukan Kecamatan Sumbang Kabupaten Banyumas. Fakultas Ekonomi dan Bisnis, Universitas Jenderal Soedirman

[25] Nia Karniawati. 2015. Hakekat Ilmu Pemerintahan (Kajian secara Filsafat). Prodi Ilmu Pemerintahan FISIP Unikom.

[26] Ratna Azis Prasetyo. 2016. Peranan BUMDes Dalam Pembangunan Dan Pemberdayaan Masyarakat Di Desa Pejambon Kecamatan Sumberrejo Kabupaten Bojonegoro. Departemen Sosiologi FISIP Universitas Airlangga

[27] Rizka Hayyuna, Ratih Nur Pratiwi, Lely Indah Mindarti. 2014. Strategi Manajemen Aset BUMDes Dalam Rangka Meningkatkan Pendapatan Desa (Studi pada BUMDES di Desa Sekapuk, Kecamatan Ujungpangkah, Kabupaten Gresik). Jurusan Administrasi Publik, Fakultas Ilmu Administrasi, Universitas Brawijaya, Malang.

[28] Robiyatul Adawiyah. 2018. Strategi Pengembangan Badan Usaha Milik Desa (BUMDes) Berbasis Aspek Modal Sosial (Studi pada BUMDes Surya Sejahtera, Desa Kedungturi, Kecamatan Taman, Kabupaten Sidoarjo). Program Studi Ilmu Administrasi Negara, FISIP, Universitas Airlangga

[29] Sentosa Seimbiring. 2017. Keberadaan Badan Usaha Milik Desa Dalam Meningkatkan Pendapatan Asli Desa. Fakultas Hukum, Universitas Katolik Parahyangan.

[30] Syahran Firdaus. 2018. Fenomena Elite Capture Dalam Pengelolaan Badan Usaha Milik Desa (BUMDes): Studi kasus strategi bekerjanya kekuasaan elite dalam pengelolaan BUMDes Argosari, desa Pulosari, Kabupaten Pemalang. Universitas Gadjah Mada.

[31] Valentine Queen Chintary dan Asih Widi Lestari. 2016. Peran Pemerintah Desa Dalam Mengelola Badan Usaha Milik Desa (BUMDes). Program Studi Ilmu Administrasi Negara, FISIP, Universitas Tribhuwana Tunggadewi Malang. 